Article

\title{
Caralluma europaea (Guss.) N.E.Br.: Anti-Inflammatory, Antifungal, and Antibacterial Activities against Nosocomial Antibiotic-Resistant Microbes of Chemically Characterized Fractions
}

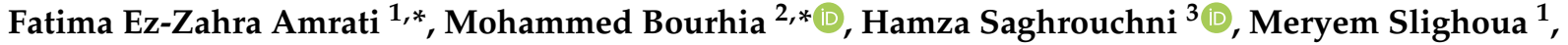

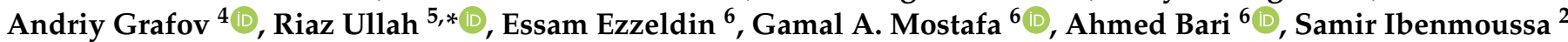 \\ and Dalila Bousta ${ }^{1}$
}

check for

updates

Citation: Amrati, F.E.-Z.; Bourhia, M.; Saghrouchni, H.; Slighoua, M.; Grafov, A.; Ullah, R.; Ezzeldin, E.; Mostafa, G.A; Bari, A.; Ibenmoussa S.; et al. Caralluma europaea (Guss.) N.E.Br.: Anti-Inflammatory, Antifungal, and Antibacterial Activities against Nosocomial Antibiotic-Resistant Microbes of Chemically Characterized Fractions. Molecules 2021, 26, 636. https:// doi.org/10.3390/molecules26030636

Academic Editors: Lillian Barros, Raffaele Capasso and Lorenzo Di Cesare Mannelli

Received: 2 January 2021

Accepted: 22 January 2021

Published: 26 January 2021

Publisher's Note: MDPI stays neutral with regard to jurisdictional claims in published maps and institutional affiliations.

Copyright: (c) 2021 by the authors. Licensee MDPI, Basel, Switzerland. This article is an open access article distributed under the terms and conditions of the Creative Commons Attribution (CC BY) license (https:/ / creativecommons.org/licenses/by/ $4.0 /)$.
1 Laboratory of Biotechnology, Health, Agrofood and Environment (LBEAS), Faculty of Sciences Dhar El Mehraz, Sidi Mohamed Ben Abdellah University, Fez 30000, Morocco; slighoua.meryem@gmail.com (M.S.); boustadalila@gmail.com (D.B.)

2 Laboratory of Chemistry, Biochemistry, Nutrition, and Environment, Faculty of Medicine and Pharmacy, University Hassan II, Casablanca 20000, Morocco; ibenmoussa@yahoo.fr

3 Department of Biotechnology, Institute of Natural and Applied Sciences, Çukurova University, Adana 01170, Turkey; hsaghrouchni@student.cu.edu.tr

4 Department of Chemistry, Faculty of Sciences, Helsinki University, 00100 Helsinki, Finland; andriy.grafov@helsinki.fi

5 Department of Pharmacognosy (MAPPRC), College of Pharmacy, King Saud University, P.O. Box 2457, Riyadh 11451, Saudi Arabia

6 Department of Pharmaceutical Chemistry, College of Pharmacy, King Saud University, P.O. Box 2457, Riyadh 11451, Saudi Arabia; esali@ksu.edu.sa (E.E.); gmostafa@ksu.edu.sa (G.A.M.); abari@ksu.edu.sa (A.B.)

* Correspondence: fatima.ezzahra.amrati@gmail.com (F.E.-Z.A.); bourhiamohammed@gmail.com (M.B.); rullah@ksu.edu.sa (R.U.)

Abstract: Caralluma europaea (Guss.) N.E.Br.: (C. europaea) is a wild medicinal plant belonging to the family Apocynaceae. It is commonly used in traditional medicines for treating several diseases. The present work aims to evaluate the anti-inflammatory, antibacterial, and antifungal potentials of C. europaea fractions including hydro ethanol (ET CE), n-butanol (But CE), and polyphenol (Poly $\mathrm{CE}$ ). The chemical composition of hydroethanol, n-butanol, and polyphenol-rich fractions from C. europaea were determined using GC-MS after silylation. The anti-inflammatory effect of hydroethanol, n-butanol, and polyphenol-rich fractions was studied by carrageenan-induced paw edema. Antibacterial and antifungal activities of hydroethanol, n-butanol, and polyphenol-rich fractions against Gram-positive bacteria, Gram-negative bacteria, and yeasts were assessed using the disc diffusion and micro-dilution assays. The findings of the chemical characterization affirmed the presence of interesting bioactive compounds in C. europaea fractions. The polyphenol-rich fraction was the best inhibitor of edema by $75.68 \%$ after $6 \mathrm{~h}$ of treatment. The hydroethanol fraction was the most active against both bacteria and yeasts. This study contributes to society as it provides potential bioactive compounds in C. europaea extract, which may help in fighting nosocomial antibiotic-resistant microbes.

Keywords: Caralluma europaea (Guss.) N.E.Br.; chemical characterization; anti-inflammatory; antibacterial; antifungal

\section{Introduction}

For a long time, medicinal plants have been used to fight diseases. It is estimated that about $80 \%$ of the population based in developing countries use herbal medications for medication purposes [1]. Due to their accessibility and affordability, natural remedies are remarkably used in low-income settings for the treatment of several diseases, including inflammation, bacterial, and fungal infections [2]. 
Inflammatory diseases, bacterial and fungal infections are prevalent in developing countries due to socioeconomic and behavioral factors such as food hygiene, sanitation, and overcrowding effects [3]. Many studies reported that chronic inflammation and bacterial infections are associated with various diseases including cancer $[4,5]$.

Chronic use of conventional drugs to fight inflammatory diseases, bacterial and fungal infections may have side effects, such as allergy, gastrointestinal disturbances, as well as drug resistance [6]. Thus, patients pay particular attention to modern drugs and look for alternative plant-based treatments. Moreover, the development of novel and effective natural-product-based plants to treat inflammation, bacterial, and fungal infections has received full attention and has become a considerable topic of several scientific communities [7].

Antimicrobial resistance is a complicated phenomenon where microbes developed resistance against commonly used antimicrobial drugs and antibiotics $[8,9]$. The tested bacteria in the present study such as Staphylococcus aureus, Pseudomonas aeruginosa, Klebsiella pneumonia, and Escherichia coli pathogens have been reported in previous works as multidrug-resistant, extensive drug-resistant, and even pan drug-resistant. In addition to the mentioned bacteria, Candida albicans is also recognized as one of the most common nosocomial agents, which is responsible for affecting more than $90 \%$ of patients with AIDS. The close association of Candida species infections and multidrug resistance is becoming belonging to the greatest growing health problem in medicines [10,11].

Caralluma europaea (C. europaea) is a leafless wild succulent species distributed in many Mediterranean countries including Morocco, Jordan, Egypt, Algeria, Tunisia, Libya, Spain, and Italy [12].

In traditional medicines, the aerial parts of $C$. europaea are recommended for being used as a juice, or as a powder mixed with honey or milk to treat inflammation, ulcer, diabetes, and bacterial infections [13]. Due to its presumed therapeutic effects, earlier literature reported some pharmacological activities of $C$. europaea such as antinociceptive, antiulcer, antihyperglycemic antioxidant, and cytotoxic activities [13-15].

Despite the wide use of $C$. europaea in traditional medicine, no well-developed research can provide scientific data on the potential activities of this species. Hence, the current study was conducted to study the chemical composition, anti-inflammatory, antibacterial, and antifungal activities of C. europaea extracts.

\section{Results}

\subsection{GC-MS Analysis}

The extraction yield of hydroethanol, butanol, and polyphenol-rich fractions were $13.25 \%, 12.9 \%$, and $7.96 \%$ respectively. The chemical composition of each fraction from C. europaea (hydroethanol, $n$-butanol, and polyphenol) was determined by GC-MS after silylation. Results are summarized in Figures 1-3, and Tables 1-3.

Silylation followed by GC-MS analysis of the hydroethanol fraction from C. europaea revealed the presence of several compounds including coumaran-3-one, 2-phenylthiophene, oxalic acid, proline, and propanoic acid, 2-[(trimethylsilyl)oxy]-, trimethylsilyl ester (Figure 1 and Table 1). Analysis of the polyphenol-rich fraction showed the presence of benzoic acid, 4-methyl-2-trimethylsilyloxy-, trimethylsilyl ester, phenol 4-(3,4-dihydro2,2,4-trimethyl-2H-1-benzopyran-4-yl), cinnamic acid, flavone, 2'-methoxy-, butyric acid, and p-coumaryl alcohol (Figure 2 and Table 2). Analysis of the n-butanol fraction affirmed the presence of benzoic acid 4-methyl-2-trimethylsilyloxy, trimethylsilyl ester, elymoclavin, benzenepropanoic acid, trimethylsilyl ester, and 5-hydroxy-6-methoxy-2-methyl-3phenylbenzofuran (isoparvifuran) (Figure 3 and Table 3). 


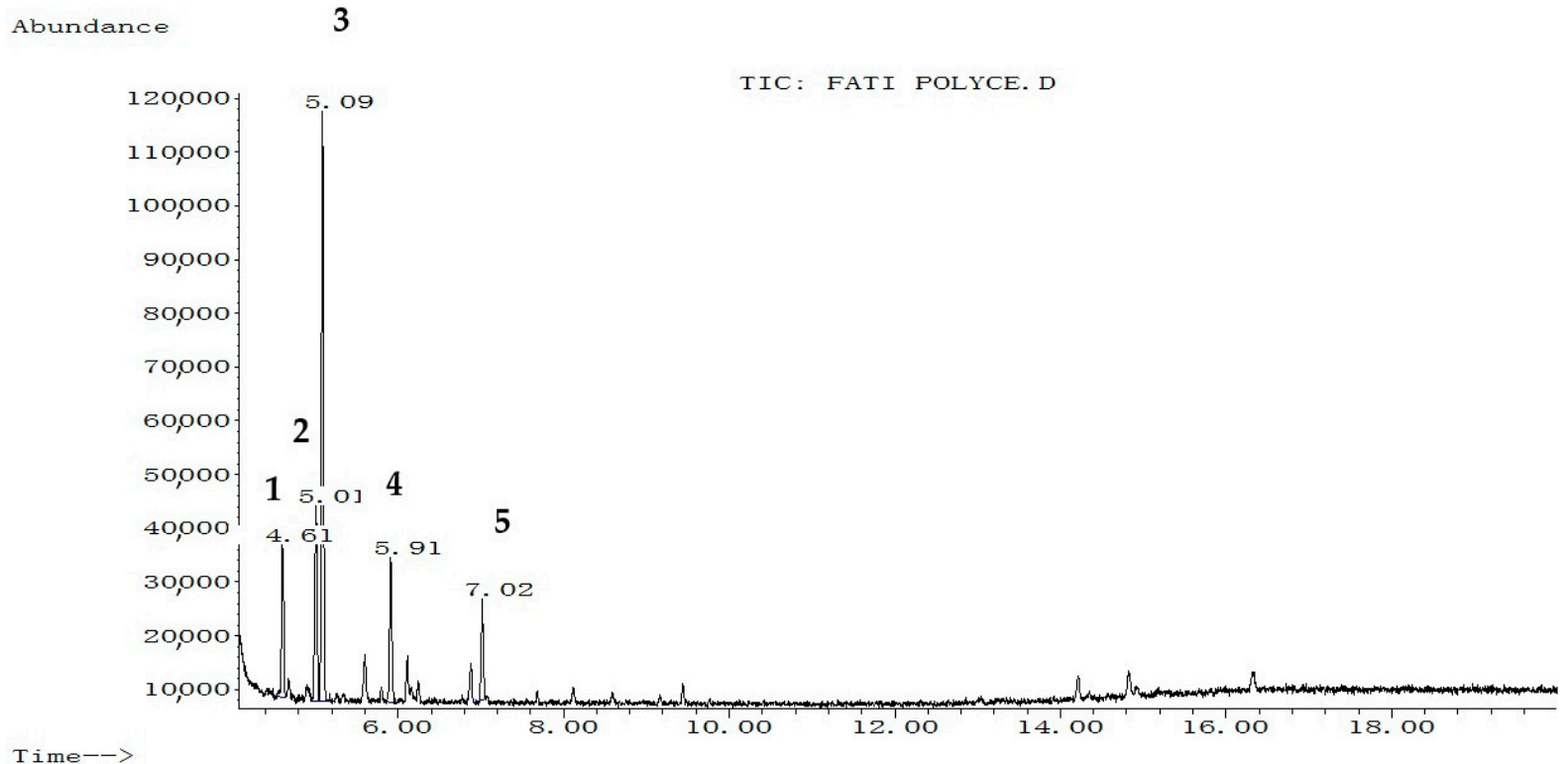

Figure 1. Chromatographic profile of hydroethanol fraction of C. europaea after silylation. 1: Coumaran-3-one; 2: 2Phenylthiophene; 3: Oxalic acid, 4: Proline; 5: Propanoic acid, 2-[(trimethylsilyl)oxy]-, trimethylsilyl ester.

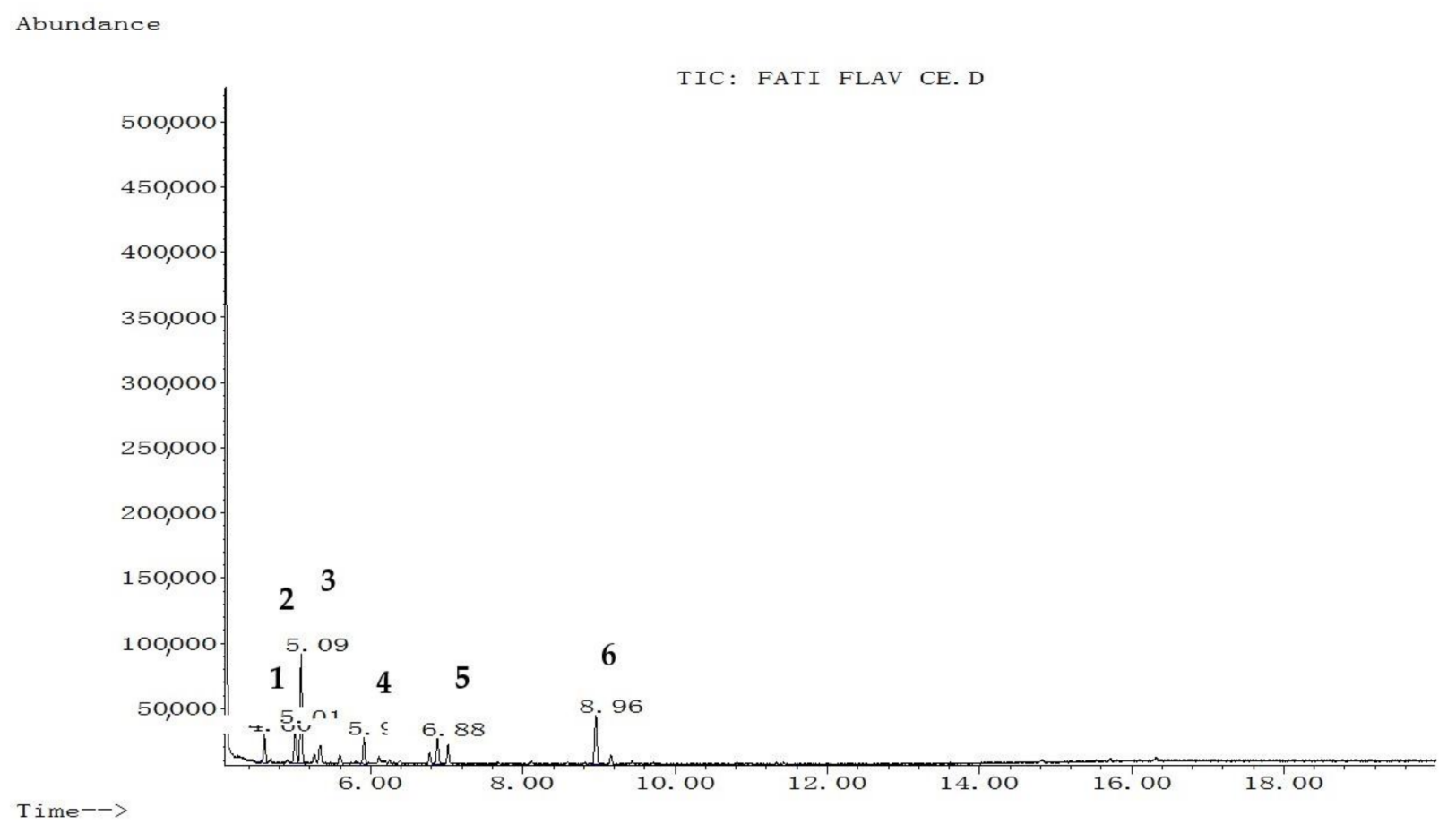

Figure 2. Chromatographic profile of the polyphenol-rich fraction of C. europaea after silylation. 1: Benzoic acid, 4-methyl-2trimethylsilyloxy-, trimethylsilyl ester; 2: Phenol4-(3,4-dihydro-2,2,4-trimethyl-2H-1-benzopyran-4-yl); 3: Cinnamic acid; 4: Flavone, 2'-methoxy-; 5: Butyric acid; 6: p-coumaryl alcohol. 


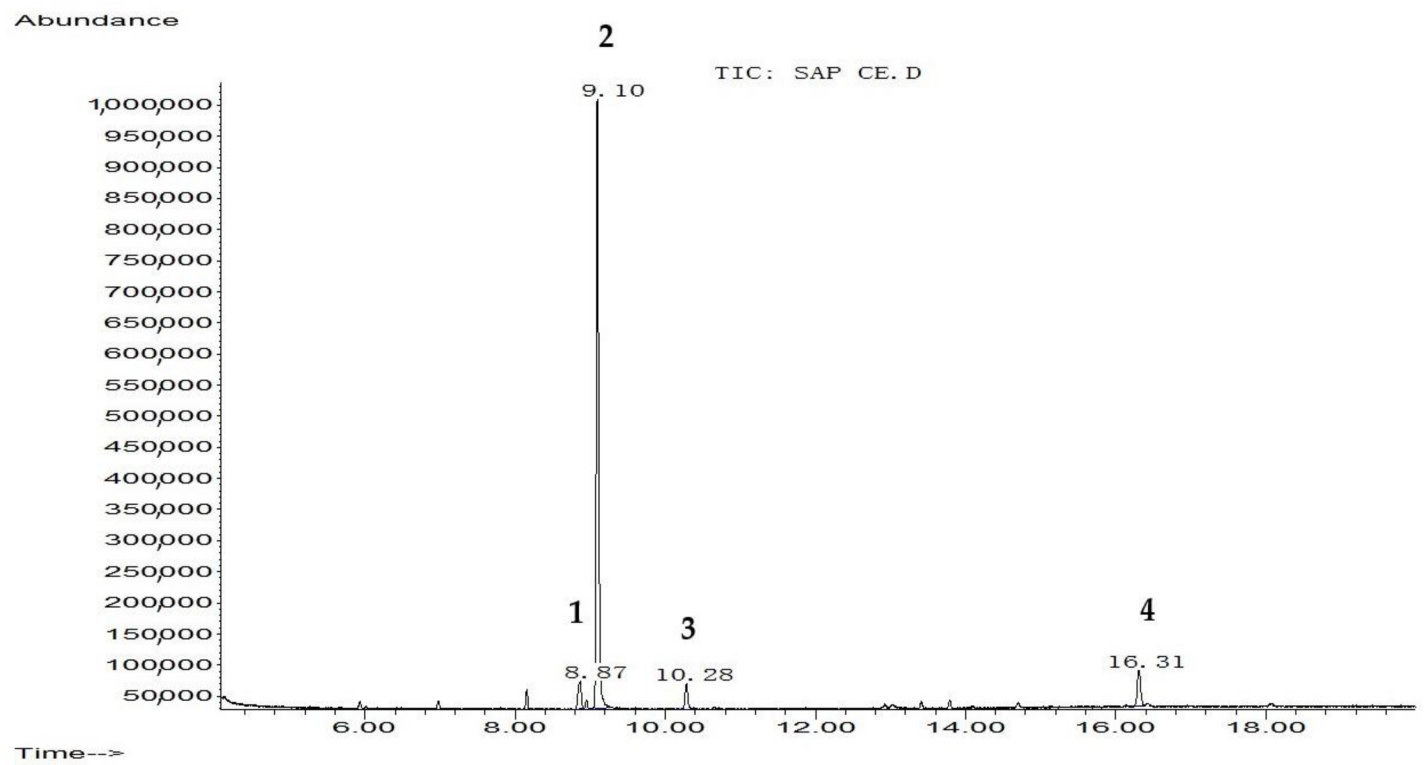

Figure 3. Chromatographic profile of n-butanol fraction of C. europaea after silylation. 1: Benzoic acid, 4-methyl-2trimethylsilyloxy-, trimethylsilyl ester; 2: Elymoclavin; 3: Benzenepropanoic acid, trimethylsilyl ester; 4: 5-Hydroxy-6methoxy-2-methyl-3-phenylbenzofuran (isoparvifuran).

Table 1. GC-MS identified compounds in the hydroethanol fraction of C. europaea.

\begin{tabular}{cccccc}
\hline $\begin{array}{c}\text { Rank Peak } \\
\text { No }\end{array}$ & Name of Compound & $\begin{array}{c}\text { Molecular } \\
\text { Weight (g/mol) }\end{array}$ & $\begin{array}{c}\text { Structural } \\
\text { Formula }\end{array}$ & $\begin{array}{c}\text { \% } \\
\text { Area }\end{array}$ & RT (min) \\
\hline 1 & Coumaran-3-one & 134.13 & $\mathrm{C}_{8} \mathrm{H}_{6} \mathrm{O}_{2}$ & 12.388 & 4.61 \\
2 & 2-Phenylthiophene & 160 & $\mathrm{C}_{10} \mathrm{H}_{8} \mathrm{~S}$ & 17.615 & 5.01 \\
3 & Oxalic acid & 90.03 & $\mathrm{C}_{2} \mathrm{H}_{2} \mathrm{O}_{4}$ & 49.122 & 5.09 \\
4 & Proline & 115.13 & $\mathrm{C}_{5} \mathrm{H}_{9} \mathrm{NO}_{2}$ & 12.718 & 5.91 \\
5 & Propanoic acid, 2-[(trimethylsilyl)oxy]-, & 234 & $\mathrm{C}_{9} \mathrm{H}_{22} \mathrm{O}_{3} \mathrm{Si}_{2}$ & 8.157 & 7.02 \\
\hline
\end{tabular}

Table 2. GC-MS identified compounds in the polyphenol-rich fraction of C. europaea.

\begin{tabular}{|c|c|c|c|c|c|}
\hline $\begin{array}{l}\text { Rank Peak } \\
\text { No }\end{array}$ & Name of Compound & $\begin{array}{c}\text { Molecular } \\
\text { Weight (g/mol) }\end{array}$ & $\begin{array}{l}\text { Structural } \\
\text { Formula }\end{array}$ & $\begin{array}{c}\% \\
\text { Area }\end{array}$ & $\begin{array}{c}\mathrm{RT} \\
(\mathrm{min})\end{array}$ \\
\hline 1 & $\begin{array}{l}\text { Benzoic acid, 4-methyl-2-trimethylsilyloxy-, } \\
\text { trimethylsilyl ester }\end{array}$ & 296 & $\mathrm{C}_{14} \mathrm{H}_{24} \mathrm{O}_{3} \mathrm{Si}_{2}$ & 9.610 & 4.60 \\
\hline 2 & $\begin{array}{l}\text { Phenol4-(3,4-dihydro-2,2,4-trimethyl-2H-1- } \\
\text { benzopyran-4-yl) }\end{array}$ & 268 & $\mathrm{C}_{18} \mathrm{H}_{20} \mathrm{O}_{2}$ & 14.013 & 5.01 \\
\hline 3 & Cinnamic acid & 148.16 & $\mathrm{C}_{9} \mathrm{H}_{8} \mathrm{O}_{2}$ & 37.271 & 5.09 \\
\hline 4 & Flavone, $2^{\prime}$-methoxy- & 252 & $\mathrm{C}_{16} \mathrm{H}_{12} \mathrm{O}_{3}$ & 9.297 & 5.9 \\
\hline 5 & Butyric acid & 88.11 & $\mathrm{C}_{4} \mathrm{H}_{8} \mathrm{O}_{2}$ & 9.859 & 6.88 \\
\hline 6 & $p$-coumaryl alcohol & 150.17 & $\mathrm{C}_{9} \mathrm{H}_{10} \mathrm{O}_{2}$ & 19.950 & 8.96 \\
\hline
\end{tabular}

Table 3. GC-MS identified compounds in the n-butanol fraction of C. europaea.

\begin{tabular}{|c|c|c|c|c|c|}
\hline $\begin{array}{l}\text { Rank Peak } \\
\text { No }\end{array}$ & Name of Compound & $\begin{array}{c}\text { Molecular } \\
\text { Weight (g/mol) }\end{array}$ & $\begin{array}{l}\text { Structural } \\
\text { Formula }\end{array}$ & $\begin{array}{c}\% \\
\text { Area }\end{array}$ & $\begin{array}{c}\mathrm{RT} \\
(\mathrm{min})\end{array}$ \\
\hline 1 & $\begin{array}{l}\text { Benzoic acid, 4-methyl-2-trimethylsilyloxy-, } \\
\text { trimethylsilyl ester }\end{array}$ & 296 & $\mathrm{C}_{14} \mathrm{H}_{24} \mathrm{O}_{3} \mathrm{Si}_{2}$ & 5.536 & 8.87 \\
\hline 2 & Elymoclavin & 254.33 & $\mathrm{C}_{16} \mathrm{H}_{18} \mathrm{~N}_{2} \mathrm{O}$ & 83.829 & 9.10 \\
\hline 3 & Benzenepropanoic acid, trimethylsilyl ester & 222 & $\mathrm{C}_{12} \mathrm{H}_{18} \mathrm{O}_{2} \mathrm{Si}$ & 3.758 & 10.28 \\
\hline 4 & $\begin{array}{l}\text { 5-Hydroxy-6-methoxy-2-methyl-3-phenylbenzofuran } \\
\text { (isoparvifuran) }\end{array}$ & 254 & $\mathrm{C}_{16} \mathrm{H}_{14} \mathrm{O}_{3}$ & 6.877 & 16.31 \\
\hline
\end{tabular}




\subsection{Anti-Inflammatory Activity}

The results of the anti-inflammatory effects of C. europaea fractions such as hydroethanol, n-butanol, and polyphenol-rich fractions at doses 100, 100, and $50 \mathrm{mg} / \mathrm{Kg}$ respectively, are summarized in Table 4.

Table 4. Anti-inflammatory effects of C. europaea fractions on carrageenan-induced paw edema.

\begin{tabular}{|c|c|c|c|c|c|}
\hline \multirow{2}{*}{$\begin{array}{l}\text { Treatment } \\
\text { Groups }\end{array}$} & \multirow{2}{*}{$\begin{array}{l}\text { Basal Diameter } \\
(\mathrm{cm})\end{array}$} & \multicolumn{4}{|c|}{ Paw Size after the Carrageenan Injection (Mean \pm SEM)/Percent Inhibition of Edema } \\
\hline & & 3 Hour & 4 Hour & 5 Hour & 6 Hour \\
\hline $\mathrm{NaCl}$ & $\begin{array}{c}2.3 \pm \\
0.01581\end{array}$ & $\begin{array}{c}2.6 \pm \\
0.04472\end{array}$ & $\begin{array}{l}2.8 \pm \\
0.0547\end{array}$ & $\begin{array}{l}2.68 \pm \\
0.0158\end{array}$ & $\begin{array}{c}2.520 \pm \\
0.0209\end{array}$ \\
\hline $\begin{array}{l}\text { Indomethacin }^{\circledR} \\
10 \mathrm{mg} / \mathrm{kg}\end{array}$ & $\begin{array}{l}2.220 \pm \\
0.03742\end{array}$ & $\begin{array}{c}2.420 \pm \\
0.03742^{* *} \\
33.33 \%\end{array}$ & $\begin{array}{l}2.362 \pm \\
0.0348^{*} \\
71.60 \%\end{array}$ & $\begin{array}{c}2.300 \pm \\
0.0273 \\
78.95 \%\end{array}$ & $\begin{array}{c}2.266 \pm \\
0.0331 \\
79.09 \%\end{array}$ \\
\hline $\begin{array}{c}\text { ET CE } \\
100 \mathrm{mg} / \mathrm{kg}\end{array}$ & $\begin{array}{l}2.340 \pm \\
0.02449\end{array}$ & $\begin{array}{c}2.556 \pm \\
0.0250 * * * \\
28 \%\end{array}$ & $\begin{array}{c}2.534 \pm \\
0.0271^{* * *} \\
61.20 \%\end{array}$ & $\begin{array}{c}2.474 \pm \\
0.0208^{* *} \\
64.74 \%\end{array}$ & $\begin{array}{c}2.398 \pm \\
0.0217 \\
73.64 \%\end{array}$ \\
\hline $\begin{array}{l}\text { Poly CE } \\
50 \mathrm{mg} / \mathrm{kg}\end{array}$ & $\begin{array}{l}2.315 \pm \\
0.00866\end{array}$ & $\begin{array}{c}2.523 \pm \\
0.0062 \text { *** } \\
30.38 \%\end{array}$ & $\begin{array}{c}2.473 \pm \\
0.0062^{* * *} \\
68.5 \%\end{array}$ & $\begin{array}{c}2.410 \pm \\
0.0070^{* * *} \\
75 \%\end{array}$ & $\begin{array}{c}2.369 \pm \\
0.0060^{* * *} \\
75.68 \%\end{array}$ \\
\hline $\begin{array}{c}\text { But CE } \\
100 \mathrm{mg} / \mathrm{kg}\end{array}$ & $\begin{array}{l}2.350 \pm \\
0.02887\end{array}$ & $\begin{array}{c}2.555 \pm \\
0.0295 * * * \\
31.67 \%\end{array}$ & $\begin{array}{c}2.503 \pm \\
0.0246^{* *} \\
69.50 \%\end{array}$ & $\begin{array}{c}2.440 \pm \\
0.0291 \\
76.32 \%\end{array}$ & $\begin{array}{c}2.401 \pm \\
0.0282 \\
76.70 \%\end{array}$ \\
\hline
\end{tabular}

Values are expressed as means \pm SEM. $(n=5), p<0.05$ considered statistically significant compared to the control and reference drug (indomethacin $10 \mathrm{mg} / \mathrm{mL}$ ). *: Significant, ${ }^{* *}$ : high significant; ${ }^{* * *}$ : extremely significant.

The oral administration of hydroethanol, n-butanol, and polyphenol-rich fractions at doses 100,100, and $50 \mathrm{mg} / \mathrm{Kg}$ induced significant anti-inflammatory effects when compared to the indomethacin drug (positive control). The animals treated with $100 \mathrm{mg} / \mathrm{Kg}$ of n-butanol fraction showed maximum inhibition of the paw edema, which reached $69.50 \%, 76.32 \%$, and $76.70 \%$ after 4,5 , and $6 \mathrm{~h}$ of treatment respectively. No significant difference was observed between these results and indomethacin used as a standard drug at a dose of $10 \mathrm{mg} / \mathrm{Kg}(p>0.05)$ (Table 4). The inhibited paw edema in mice treated with hydroethanolic $(100 \mathrm{mg} / \mathrm{Kg})$, and polyphenol $(50 \mathrm{mg} / \mathrm{kg})$ rich fractions reached $75.68 \%$ and $73.64 \%$, respectively, after $3 \mathrm{~h}$ of the carrageenan intradermal injection.

\subsection{Antibacterial Activity}

The antibacterial activity of hydroethanol (ET CE), n-butanol (But CE), and polyphenol (Poly CE) rich fractions were evaluated using the disc diffusion method and micro-dilution assays. The results are presented in Tables 5 and 6, as well as Supplementary material.

Table 5. MCI results of C. europaea fractions against bacterial species in $(\mathrm{mg} / \mathrm{mL})$.

\begin{tabular}{ccccc}
\hline \multirow{2}{*}{ Fractions } & \multicolumn{3}{c}{ Gram-Negative Bacteria } & Gram-Positive Bacteria \\
\cline { 2 - 5 } & Escherichia coli & Klebsiella pneumoniae & Pseudomonas aeruginosa & Staphylococcus aureus \\
\hline But CE & 6.25 & 25 & 6.25 & 6.25 \\
Poly CE & 6.25 & 12.5 & 12.5 & 3.125 \\
ET CE & 12.5 & 12.5 & 25 & 12.5 \\
STR & 0.25 & 0.003 & Resistant & 0.062 \\
AMP & Resistant & Resistant & Resistant & Resistant \\
\hline
\end{tabular}


Table 6. Inhibition zone diameter of C. europaea fractions against bacterial species in (mm).

\begin{tabular}{ccccc}
\hline \multirow{2}{*}{ Fractions } & \multicolumn{3}{c}{ Gram-Negative Bacteria } & Gram-Positive Bacteria \\
\cline { 2 - 5 } & Escherichia coli & Klebsiella pneumoniae & Pseudomonas aeruginosa & Staphylococcus aureus \\
\hline But CE & 10 & 7 & Resistant & 9 \\
Poly CE & Resistant & Resistant & Resistant & 8 \\
ET CE & 9 & 12 & 10 & 12 \\
Streptomycine & Resistant & Resistant & Resistant & 9 \\
Ampicilline & Resistant & Resistant & Resistant & Resistant \\
\hline
\end{tabular}

Table 5 represents the results of the minimum inhibitory concentration (MICs)obtained by using the micro-dilution method. All fractions showed almost equal effects with concentrations ranged from 6.25 to $12.5 \mathrm{mg} / \mathrm{mL}$ against Gram-negative bacteria. Regarding Gram-positive bacteria, the MIC of the Poly CE was $3.125 \mathrm{mg} / \mathrm{mL}$ against Staphylococcus aureus. The inhibition zone diameter bioassay showed that $\mathrm{CE}$ has a significant activity with an inhibition zone diameter of $12 \mathrm{~mm}$ against Klebsiella pneumoniae and Staphylococcus aureus (Table 6).

According to the results presented in Table 7, ET CE showed significant antifungal activity against Candida albicans and Saccharomyces cerevisiae with MIC of $6.25 \mathrm{mg} / \mathrm{mL}$ and $12.5 \mathrm{mg} / \mathrm{mL}$ respectively. Concerning the inhibition zone diameter assay (Table 8), But CE and ET CE induced an inhibition zone diameter against Saccharomyces cerevisiae and Candida albicans with $12 \mathrm{~mm}$ and $14 \mathrm{~mm}$ respectively.

Table 7. MCI of C. europaea fractions against yeasts in $(\mathrm{mg} / \mathrm{mL})$.

\begin{tabular}{ccc}
\hline Fractions & Candida albicans & Saccharomyce sereveseae \\
\hline But CE & 25 & 25 \\
Poly CE & 50 & 50 \\
ET CE & 6.25 & 12.5 \\
Fluconazole & 0.4 & 0.2 \\
\hline
\end{tabular}

Table 8. Inhibition diameter of C. europaea fractions against yeasts in (mm).

\begin{tabular}{ccc}
\hline Fractions & Candida albicans & Saccharomyce sereveseae \\
\hline But CE & Resistant & 14 \\
Poly CE & Resistant & Resistant \\
ET CE & 12 & Resistant \\
Fluconazole & 21 & 27 \\
\hline
\end{tabular}

\section{Discussion}

C. europaea is a medicinal plant historically used in traditional folk medicines to treat diseases including inflammation, bacterial, and fungal infections [15]. However, up to date, no more scientific data has been reported in the literature investigating the pharmacological activities of this plant. As consequence, the currents work was undertaken to study antibacterial, antifungal, and anti-inflammatory activities of C. europaea growing in Morocco.

In the last decades, the prevalence of inflammatory diseases has increased throughout the world. Steroidal and non-steroidal anti-inflammatory drugs are mostly used in treating these diseases. However, their use for a long time may have serious side effects that can be mortal. This can explain the interest of many people in herbal remedies as a potential alternative treatment for inflammatory diseases [16]. The inflammatory process is a complex biological response of the body including the overproduction of cytokines or pro-inflammatory molecules through the activation of different signaling pathways.

The findings obtained in the present work showed that hydroethanol, $n$-butanol, and polyphenol-rich fractions from C. europaeas showed an important anti-inflammatory effect. 
The observed inflammatory effect can be due to benzoic acid and isoparvifuran compounds identified in the $n$-butanol fraction chemically characterized by GC-MS (Figure 3 and Table 3). Benzoic acid derivatives were found to have a potent effect to inhibit cyclooxygenase activity. Consequently, these chemicals can act as anti-inflammatory agents and can be used to treat various inflammatory disorders $[17,18]$. Isoparvifuran and flavones compounds displayed potent anti-inflammatory activity as reported elsewhere [19-21].

The anti-inflammatory activity of C. europaea polyphenol-rich fraction might be also related to phytochemical compounds identified by HPLC such as ferulic acid, quercetin, myricetin, gallic acid, and hesperetin, as reported in the earlier work [15]. Many literature studies reported that ferulic acid, quercetin, myricetin, gallic acid, and hesperetin were found to possess potent anti-inflammatory properties that act through different biological pathways [5,22-25]. These findings are in agreement with many literature studies reporting that ethanolic extracts from Caralluma arabica and Caralluma attenuate as close species to our studied plant exhibited significant anti-inflammatory effects via their chemically identified compounds such as luteolin- $4 \%-O$-neohesperidoside,lutolin- $4 \%-O-$ [a-(L-rhamnopyranosyl-(12)-b-D-glucopyranoside)] [26,27]. Propanoic acid identified by GC-MS in the hydroethanol fraction of C. europaea as well as cinnamic acid can be also responsible for the observed anti-inflammatory effects (Figure 1 and Table 1) (Figure 2 and Table 2) [28-30].

Regarding antibacterial activities investigated in the present work, almost all fractions from C. europaea were more active on Gram-positive bacteria and yeasts. Our results showed that Gram-positive bacteria were generally more sensitive to plant fractions than Gramnegative bacteria. These results were closely similar to some studies showing the sensitivity of Gram bacteria to plant extracts more than Gram-negative [31,32]. The structure of the cell envelope may be responsible for this difference since Gram-negative bacteria have additional periplasmic space and a rigid layer between the outer and cytoplasmic membrane, which limits the diffusion of hydrophobic compounds [33]. Our results showed that $P$. aeruginosa (Gram-negative) was the most resistant bacteria to plant fractions. This result consistent with the previous literature, which showed the resistance of $P$. aeruginosa to conventional antimicrobials [34-36].

The antibacterial effect of our fractions can be attributed to the effect of benzoic acid (Figure 3 and Table 3) since earlier work reported the inhibitory effect of benzoic acid on the proliferation of bacteria and yeasts [37]. Proline-rich antimicrobial peptides (PR-AMPs) (Figure 1 and Table 1) characterized by a high content of proline residues can play a role in inhibiting several pathogenic bacteria and yeasts [38]. Cinnamic acid (Figure 2 and Table 2) was found to have antibacterial activity by disrupting bacteria membranes [39]. Benzenepropanoic acid (Figure 3 and Table 3,) was also reported to be effective against different bacteria such as Escherichia coli, Klebsiella pneumonia, Pseudomonas aeruginosa, and some fungi including candida albicans [40]. Moreover, carboxylic acids, including oxalic acid and propanoic acid identified by GC-MS analysis in the hydroethanol fraction of C. europaea (Figure 1 and Table 1), might be involved in antifungal activity [41,42]. Moreover, the hydrophobicity of these compounds facilitates their penetration between the lipid components of bacterial membrane and mitochondria, which increases the membrane permeability and leads to the eventual death of bacteria $[43,44]$. This mechanism of action could be involved in the antibacterial effect induced by our plant fractions. Furthermore, the antimicrobial effect can result from individual compounds or synergy between a lot [45]. The findings found in this work are in agreement with the previous literature, which showed that essential oils from C. europaea exhibited antibacterial activities against Gram-positive bacteria such as K. pneumonia and P. aeruginosa. Potential antifungal effects of Caralluma. europaea essential oil might also be reported elsewhere [46].

The antimicrobial effect shown by this plant can be attributed to the presence of monoterpene hydrocarbons, including $\alpha$-terpinene, $\alpha$-pinene, and $\beta$-pinene, and oxygenated monoterpenes. These compounds showed antimicrobial activity by inducing 
cell integrity perturbation, inhibition of cell respiration, as well as increasing membrane permeability $[31,44,47]$.

\section{Materials and Methods}

\subsection{Solvents and Reagents}

Dichloromethane, ethanol, methanol, chloroform, ethyl acetate, n-butanol, n-hexane, and N-Trimethylsilyl-N-methyl trifluoroacetamide were purchased from Sigma Aldrich (Munich, Germany).

\subsection{Plant Material}

C. europaea was collected from the Imouzzer region at the Middle Atlas Mountains, Morocco in April 2018. The plant was authenticated by the botanist Bari Amina, and given the voucher specimen\#18I4C001 before being deposited at the herbarium of the Department of Biology, Faculty of Sciences Dhar El Mahraz, Sidi Mohammed BenAbdallah Fes University, Morocco. Afterward, the aerial parts were dried in the shade in a wellventilated room for one week before being ground into powder using a blender.

\subsection{Animal Material}

Weighing between 170 and $246 \mathrm{~g}$, male and female adult Wistar rats (ethic approval number: 04/2019/LBEAS) turn 8 weeks of age were used to perform this work. Animals were obtained from the animal house of the Department of Biology, Faculty of Sciences Dhar El Mahraz, Sidi Mohammed Ben Abdallah Fes University, Morocco. Animals were housed under controlled laboratory conditions with a temperature of $23 \pm 2{ }^{\circ} \mathrm{C}$ and $12 \mathrm{~h}$ light/dark cycle. They were also allowed free access to food and water ad libitum. The Animal Ethics Review Committee at the faculty of Sciences, Fez University Morocco, reviewed and approved this study. The use of laboratory animals in all experimental procedures was conducted according to the ethical guidelines for the care and the use of laboratory animals [48].

\subsection{Extraction of Hydroethanol, n-Butanol, and Polyphenol-Rich Fractions from C. europaea}

\subsubsection{Preparation of Hydroethanol and $n$-Butanol Fractions}

A total of $10 \mathrm{~g}$ of powder of C. europaea was extracted with $100 \mathrm{~mL}$ of hydroalcoholic solution ( $7: 3 \mathrm{v} / \mathrm{v}$ Alcohol: distilled water) for $15 \mathrm{~min}$ at $25^{\circ} \mathrm{C}$ using the sonicator (Model GT Sonic). The mixture was filtered before being concentrated at $40{ }^{\circ} \mathrm{C}$ under vacuum using a rotary evaporator (model BÜCHI 461) [15]. The residue was then stored at $4{ }^{\circ} \mathrm{C}$ until further use.

\subsubsection{Preparation of the Polyphenol-Rich Fraction}

The dried powder of C. europaea aerial parts (10 g) was extracted three times with $30 \mathrm{~mL}$ of methanol. Thereafter, the mixture was concentrated under reduced pressure and low temperature. The dry extract obtained was dissolved in $50 \mathrm{~mL}$ of water and successively extracted three times again with $20 \mathrm{~mL}$ of hexane, chloroform, and ethyl acetate. Afterward, the ethyl acetate layer was evaporated at $40{ }^{\circ} \mathrm{C}$ under vacuum using a rotary evaporator (Model BÜCHI 461). The residue was redissolved in $30 \mathrm{~mL}$ of water and freeze-dried to obtain the polyphenol extract [49]. The residue was then stored at $4{ }^{\circ} \mathrm{C}$ until further use.

\subsection{GC-MS Analysis}

One milligram of each fraction (hydroethanol, $n$-butanol, and polyphenol-rich fraction) was extracted with $0.5 \mathrm{~mL}$ of dichloromethane. Afterward, $200 \mu \mathrm{L}$ of $N$-Trimethylsilyl$N$-methyl trifluoroacetamide (MSTFA) was added to the mixture before being incubated at $37^{\circ} \mathrm{C}$ for $30 \mathrm{~min} .0 .1 \mu \mathrm{L}$ of each final extract was injected into the GC-MS apparatus equipped with a capillary column model number (Agilent 19091S-433; Diameter: 0.25 mm, Length: $30 \mathrm{~m}$, Film thickness: $0.25 \mu \mathrm{m}$ ) [50]. The oven temperature program was set to 
60-300 ${ }^{\circ} \mathrm{C}$ for $10 \mathrm{~min}$ and then maintained at $300{ }^{\circ} \mathrm{C}$ for $20 \mathrm{~min}$. The injector temperature was set to $260^{\circ} \mathrm{C}$, and the detector temperature to $250^{\circ} \mathrm{C}$. Helium was used as a carrier gas with a total flow of $31.4 \mathrm{~mL} / \mathrm{min}$ and the split ratio was set to $30: 1$. The identification of the silylated compounds was conducted by comparing the retention times with those of the standards obtained from the database of the GC-MS Wiley 7n.1.

\subsection{Anti-Inflammatory Activity}

The anti-inflammatory effect of each studied fraction (hydroethanol, n-butanol, and polyphenol) was evaluated by carrageenan-induced paw edema according to the method described in the literature [51,52]. Animals were divided into five groups with 5 in each group and then treated as follows:

Group 1: negative control $(0.9 \% \mathrm{NaCl})$

Group 2: positive control (10 $\mathrm{mg} / \mathrm{Kg}$ of indomethacin)

Group 3: hydroethanol fraction $(100 \mathrm{mg} / \mathrm{Kg})$

Group 4: polyphenol-rich fraction $(50 \mathrm{mg} / \mathrm{Kg})$

Group 5: n-butanol fraction $(100 \mathrm{mg} / \mathrm{Kg})$

After one hour of gastric gavage, the inflammation was induced by injecting $0.1 \mathrm{~mL}$ of the carrageenan agent in $0.9 \%$ saline solution into the right-hand paw of rats. The initial paw size was taken before the injection of carrageenan and after $3,4,5$, and $6 \mathrm{~h}$ of treatment. The average increase in the paw size of each group was determined and compared to both the positive and the negative control. The percentage of inhibition of edema was calculated as follows:

$$
\% \text { inhibition }=((\text { St-S0 }) \text { control }-(\text { St-So }) \text { treated } /(\text { St-S0 }) \text { control }) \times 100
$$

where is the paw size after the carrageenan injection and S0 is the initial paw size before the carrageenan injection.

\subsection{Antibacterial Activity}

\subsubsection{Growing Media}

Muller Hinton Agar MHA medium was used for bacteria growth, and the Sabouraud SB medium was used for yeast growth. Micro-dilution technique for both yeast and bacteria was done using Sabouraud SBB and Muller Hinton MHB respectively. All media were autoclaved at $120^{\circ} \mathrm{C}$ for $20 \mathrm{~min}$ before the use [53].

\subsubsection{Bacterial and Yeast Strains}

The antimicrobial activity of the studied fractions was carried out using Gram-positive bacteria; Staphylococcus aureus, and Gram-negative bacteria; Escherichia coli (ATB: 57) B6N, Pseudomonas aeruginosa, and Klebsiella pneumonia. The antifungal activity of the studied fractions was studied using Candida albicans ATCC10231 and Saccharomyces cerevisiae ATCC9763.

\subsubsection{Inoculum Standardization}

The microbial inoculum was performed by taking 3 colonies from the fresh culture (24-h), which were aseptically collected and suspended in $0.9 \%$ sterile saline solution with a density of $0.5 \mathrm{McF}$ arland [54]. The bacterial suspensions were adjusted to have approximately 1-2 $\times 10^{8} \mathrm{CFU} / \mathrm{mL}$, and the yeast suspensions $1-5 \times 10^{6} \mathrm{CFU} / \mathrm{mL}$. The absorbance of the solution was read by a UV-Visible spectrophotometer (Agilent technologies, Munich, Germany) (Selecta, E. U) at $\lambda=625 \mathrm{~nm}$ [55].

\subsubsection{Disc Diffusion Method}

The plates containing the agar medium MH and YPG were inoculated with $1 \mathrm{~mL}$ of bacterial and fungal suspensions respectively before being dried for $10 \mathrm{~min}$. Afterward, $6 \mathrm{~mm}$ sterile discs were impregnated with $10 \mu \mathrm{L}$ of each tested fraction (ET CE, But CE, 
Poly CE). The antibiogram discs; $1.67 \mathrm{mg} /$ disc of ampicillin (AMP), $0.02 \mathrm{mg} /$ disc of streptomycin (STR), and the antifungal disc of $5 \mathrm{mg} /$ disc of fluconazole (FLU) were used as standard drugs. Finally, the plates inoculated with bacteria were incubated again at $37^{\circ} \mathrm{C}$ and those inoculated with yeasts at $30^{\circ} \mathrm{C}$ for $24 \mathrm{~h}$. The growth inhibition zones were determined in $\mathrm{mm}[55,56]$.

\subsubsection{Determination of the Minimum Inhibitory Concentration (MIC)}

The MIC (the minimum concentration that inhibits microbial growth) was performed using a micro-dilution assay in 96-well plates [53]. First, the ET CE, But CE, Poly CE, AMP, STR, FLU, and the microbial suspensions in $0.5 \mathrm{McFarland}$ were diluted in the broth culture medium. Afterward, $50 \mu \mathrm{L}$ of the culture medium was deposited into a microplate well previously filled with $100 \mu \mathrm{L}$ of the test fraction except wells dedicated to growth control (positive growth control). Next, micro-dilutions were made by transferring $50 \mu \mathrm{L}$ from the first well to the second successively $(1 / 2$ dilution factor $1 / 2)$. The inoculation was carried out by putting $50 \mu \mathrm{L}$ into wells of the microbial suspension whose turbidity was adjusted to $0.5 \mathrm{McF}$ arland and then were diluted in the broth culture medium. Subsequently, the microplate was incubated under agitation for $24 \mathrm{~h}$ at $37{ }^{\circ} \mathrm{C}$ for the bacteria and $30{ }^{\circ} \mathrm{C}$ for the yeasts. Then, twenty microliters of 2,3,5-triphenyl tetrazolium chloride (TTC), BIOKAR company mixed with an aqueous solution (1\%) was added to all wells for reading. Finally, a pinkish coloration appeared when there is growth after incubation for $2 \mathrm{~h}$. MIC was defined as the lowest concentration that does not produce a pink color, while the well without bacterial growth remained colorless $[17,18]$.

\subsection{Statistical Analysis}

The results obtained were expressed as means \pm SEM (standard error of the mean). Data were statistically analyzed using one-way analysis of variance (ANOVA) and student's $t$-test to perform the comparison using GraphPad Prism 7. $p$-value $<0.05$ was considered significant.

\section{Conclusions}

The chemical study of hydroethanol, $n$-butanol, and polyphenol-rich fractions from Caralluma europaea aerial parts revealed the presence of many potentially active compounds that are involved in antibacterial, antifungal, and anti-inflammatory activities shown in this research work. This study can serve patient wellbeing as it provides potentially bioactive compounds contained in C. europaea, which can be used as alternative agents to fight inflammatory diseases and nosocomial antibiotic-resistant microbes.

Supplementary Materials: The following are available online. Figure S4: Determination of minimum inhibitory concentrations (MIC) of hydroethanol, butanol, and the polyphenol-rich fraction of Caralluma europaea against Pseudomonas aeruginosa, Escherichia coli, Klebsiella pneumonia, Staphylococcus aureus, Saccharomyces cerevisiae, and Candida albicans.

Author Contributions: F.E.-Z.A. and M.B.: writing—original draft; H.S., M.S., A.G., and S.I.: formal analysis; R.U., E.E., G.A.M., A.B.: revision, and editing; D.B.: methodology and supervision. All authors have read and agreed to the published version of the manuscript.

Funding: This work was funded by Deanship of Scientific Research at King Saud University through research group no (RG-1440-100). The research was also supported by European project Horizon 2020 MSCA-RISE2016-734759-VAHVISTUS.

Institutional Review Board Statement: The institutional ethical committee of care and use of the laboratory animals at the Faculty of Sciences Dhar El Mehraz, Sidi Mohamed Ben Abdallah Fez University, Morocco, reviewed and approved the present study \# 04/2019/LBEAS.

Data Availability Statement: The data used to support the findings of this study are available from the corresponding author upon request. 
Acknowledgments: The authors extend their appreciation to the Deanship of Scientific Research at King Saud University for funding this work through research group no (RG-1440-100). The authors are also grateful for the support of the European project Horizon 2020 MSCA-RISE-2016-734759VAHVISTUS.

Conflicts of Interest: Authors declare that there are no conflict of interest.

Sample Availability: Samples of the compounds are available from the authors.

\begin{abstract}
Abbreviations
CE: Carallumaeuropaea (Guss.) N.E.Br.; C. europaea: Caralluma europaea; ET CE: Hydro-ethanol fraction from Carallumaeuropaea; But CE: n-butanol fraction from Carallumaeuropaea; Poly CE: polyphenolrich fraction from Carallumaeuropaea; AMP: Ampicillin; STR: Streptomycin; FLU: Fluconazole; MSTFA: Trimethylsilyl-N-methyl trifluoroacetamide; K. pneumonia: Klebsiella pneumonia; P. aeruginosa: Pseudomonas aeruginosa; MCI: Minimal Inhibitory Concentration; MeOH: Methanol; GC-MS: Gas Chromatography/Mass Spectrometry; MHA: Muller Hinton Agar; SB: Sabouraud; SBB: Sabouraud Broth; MHB: Muller Hinton.
\end{abstract}

\title{
References
}

1. Yang, M.; Wu, Z.; Wang, Y.; Kai, G.; Njateng, G.S.; Cai, S.; Cao, J.; Cheng, G. Acute and subacute toxicity evaluation of ethanol extract from aerial parts of Epigynum auritum in mice. Food Chem. Toxicol. 2019, 131, 110534. [CrossRef] [PubMed]

2. Ezeja, M.I.; Anaga, A.O.; Asuzu, I.U. Acute and sub-chronic toxicity profile of methanol leaf extract of Gouania longipetala in rats. J. Ethnopharmacol. 2014, 151, 1155-1164. [CrossRef] [PubMed]

3. Matu, E.N.; van Staden, J. Antibacterial and anti-inflammatory activities of some plants used for medicinal purposes in Kenya. J. Ethnopharmacol. 2003, 87, 35-41. [CrossRef]

4. Parsonnet, J. Bacterial infection as a cause of cancer. Environ. Health Perspect. 1995, 103 (Suppl. 8), $263-268$.

5. Parhiz, H.; Roohbakhsh, A.; Soltani, F.; Rezaee, R.; Iranshahi, M. Antioxidant and anti-inflammatory properties of the citrus flavonoids hesperidin and hesperetin: An updated review of their molecular mechanisms and experimental models. Phytother Res. 2015, 29, 323-331. [CrossRef] [PubMed]

6. Manouze, H.; Bouchatta, O.; Gadhi, A.C.; Bennis, M.; Sokar, Z.; Ba-M'hamed, S. Anti-inflammatory, Antinociceptive, and Antioxidant Activities of Methanol and Aqueous Extracts of Anacyclus pyrethrum Roots. Front Pharmacol. 2017, 8, 598. [CrossRef]

7. Yuan, H.; Ma, Q.; Ye, L.; Piao, G. The Traditional Medicine and Modern Medicine from Natural Products. Molecules [Internet]. 2016. Available online: https:/ / www.ncbi.nlm.nih.gov/pmc/articles/PMC6273146/ (accessed on 12 November 2020).

8. Yu, Z.; Tang, J.; Khare, T.; Kumar, V. The alarming antimicrobial resistance in ESKAPEE pathogens: Can essential oils come to the rescue? Fitoterapia 2020, 140, 104433. [CrossRef]

9. Mapara, N.; Sharma, M.; Shriram, V.; Bharadwaj, R.; Mohite, K.C.; Kumar, V. Antimicrobial potentials of Helicteres isora silver nanoparticles against extensively drug-resistant (XDR) clinical isolates of Pseudomonas aeruginosa. Appl. Microbiol. Biotechnol. 2015, 99, 10655-10667. [CrossRef]

10. Aboualigalehdari, E.; Ghafourian, S.; Sadeghifard, N.; Sekawi, Z. Is Candida albicans a cause of nosocomial infection in Iran? Rev. Med Microbiol. 2013, 24, 85-88. [CrossRef]

11. Maenza, J.R.; Merz, W.G.; Romagnoli, M.J.; Keruly, J.C.; Moore, R.D.; Gallant, J.E. Infection due to fluconazole-resistant Candida in patients with AIDS: Prevalence and microbiology. Clin. Infect. Dis. 1997, 24, 28-34. [CrossRef]

12. Dra, L.A.; Sellami, S.; Rais, H.; Aziz, F.; Aghraz, A.; Bekkouche, K.; Markouk, M.; Larhsini, M. Antidiabetic potential of Caralluma europaea against alloxan-induced diabetes in mice. Saudi J. Biol. Sci. 2019, 26, 1171-1178. [CrossRef] [PubMed]

13. Adnan, M.; Jan, S.; Mussarat, S.; Tariq, A.; Begum, S.; Afroz, A.; Shinwari, Z.K. A review on ethnobotany, phytochemistry and pharmacology of plant genus Caralluma, R. Br. J. Pharm. Pharmacol. 2014, 66, 1351-1368. [CrossRef] [PubMed]

14. Bellakhdar, J. La Pharmacopée Marocaine Traditionnelle: Médecine Arabe Ancienne Et Savoirs Populaires-Saint-Etienne [Internet]; Persée-Portail des revues scientifiques en SHS; Ibis Press: Jerusalem, Israel, 1997; Volume 35, 759p. Available online: https: //www.persee.fr/doc/horma_0984-2616_1998_num_35_1_1707_t1_0319_0000_1 (accessed on 4 December 2020).

15. Amrati, F.; Bourhia, M.; Slighoua, M.; Ibnemoussa, S.; Bari, A.; Ullah, R.; Amaghnouje, A.; Di Cristo, F.; El Mzibri, M.; Calarco, A.; et al. Phytochemical Study on Antioxidant and Antiproliferative Activities of Moroccan Caralluma europaea Extract and Its Bioactive Compound Classes. Evidence-Based Complementary and Alternative Medicine [Internet]. 2020. Available online: https:/ / www.hindawi.com/journals/ecam/2020/8409718/ (accessed on 25 April 2020).

16. Hassan, H.S.; Sule, M.I.; Musa, A.M.; Musa, K.Y.; Abubakar, M.S.; Hassan, A.S. Anti-Inflammatory Activity of Crude Saponin Extracts from Five Nigerian Medicinal Plants. Afr. J. Tradit. Complement. Altern. Med. 2011, 9, 250-255. [CrossRef] [PubMed]

17. Kumar, A.; Bansal, D.; Bajaj, K.; Sharma, S.; Srivastava, V.K. Synthesis of some newer derivatives of 2-amino benzoic acid as potent anti-inflammatory and analgesic agents. Bioorganic Med. Chem. 2003, 11, 5281-5291. [CrossRef] 
18. Mizushina, Y.; Miyazaki, S.; Ohta, K.; Hirota, M.; Sakaguchi, K. Novel anti-inflammatory compounds from Myrsine seguinii, terpeno-benzoic acids, are inhibitors of mammalian DNA polymerases. Biochim. Biophys. Acta (BBA) Gen. Subj. 2000, 1475, 1-4. [CrossRef]

19. Yin, Y.; Gong, F.-Y.; Wu, X.-X.; Sun, Y.; Li, Y.-H.; Chen, T.; Xu, Q. Anti-inflammatory and immunosuppressive effect of flavones isolated from Artemisia vestita. J. Ethnopharmacol. 2008, 120, 1-6. [CrossRef]

20. Son, N.T. A Review on the Medicinal Plant Dalbergia odorifera Species: Phytochemistry and Biological Activity. Evid. Based Complement Altern. Med. 2017, 2017, 7142370.

21. Tan, Y.-X.; Wang, H.-Q.; Chen, R.-Y. Anti-inflammatory and cytotoxic 2-arylbenzofurans from Morus wittiorum. Fitoterapia 2012, 83, 750-753. [CrossRef]

22. Yin, Z.N.; Wu, W.J.; Sun, C.Z.; Liu, H.F.; Chen, W.B.; Zhan, Q.P.; Lei, Z.G.; Xuan, X.I.; Juan, J.; Kun, Y.A.; et al. Antioxidant and Anti-inflammatory Capacity of Ferulic Acid Released from Wheat Bran by Solid-state Fermentation of Aspergillus niger. Biomed. Environ. Sci. 2019, 32, 11-21.

23. Lee, H.N.; Shin, S.A.; Choo, G.S.; Kim, H.J.; Park, Y.S.; Kim, B.S.; Kim, S.K.; Cho, S.D.; Nam, J.S.; Choi, C.S.; et al. Antiinflammatory effect of quercetin and galangin in LPS-stimulated RAW264.7 macrophages and DNCB-induced atopic dermatitis animal models. Int. J. Mol. Med. 2018, 41, 888-898. [CrossRef]

24. Cho, B.O.; Yin, H.H.; Park, S.H.; Byun, E.B.; Ha, H.Y.; Jang, S.I. Anti-inflammatory activity of myricetin from Diospyros lotus through suppression of NF- $\mathrm{B}$ and STAT1 activation and Nrf2-mediated HO-1 induction in lipopolysaccharide-stimulated RAW264.7 macrophages. Biosci. Biotechnol. Biochem. 2016, 80, 1520-1530. [CrossRef] [PubMed]

25. Kroes, B.H.; van den Berg, A.J.; Quarles van Ufford, H.C.; van Dijk, H.; Labadie, R.P. Anti-inflammatory activity of gallic acid. Planta Med. 1992, 58, 499-504. [CrossRef] [PubMed]

26. Zakaria, M.N.M.; Islam, M.W.; Radhakrishnan, R.; Chen, H.B.; Kamil, M.; Al-Gifri, A.N.; Chan, K.; Al-Attas, A. Anti-nociceptive and anti-inflammatory properties of Caralluma arabica. J. Ethnopharmacol. 2001, 76, 155-158. [CrossRef]

27. Ramesh, M.; Rao, Y.; Appa, R.A.V.N.; Prabhakar, M.C.; Seshagiri, R.C.; Muralidhar, N.; Reddy, B.M. Antinociceptive and anti-inflammatory activity of a flavonoid isolated from Caralluma attenuata. J. Ethnopharmacol. 1998, 62, 63-66. [CrossRef]

28. Mokale, S.N.; Shinde, S.S.; Elgire, R.D.; Sangshetti, J.N.; Shinde, D.B. Synthesis and anti-inflammatory activity of some 3(4,6-disubtituted-2-thioxo-1,2,3,4-tetrahydropyrimidin-5-yl) propanoic acid derivatives. Bioorganic Med. Chem. Lett. 2010, 20, 4424-4426. [CrossRef] [PubMed]

29. Takeda, Y.; Tanigawa, N.; Sunghwa, F.; Ninomiya, M.; Hagiwara, M.; Matsushita, K.; Koketsu, M. Morroniside cinnamic acid conjugate as an anti-inflammatory agent. Bioorganic Med. Chem. Lett. 2010, 20, 4855-4857. [CrossRef]

30. Godoy, M.E.; Rotelli, A.; Pelzer, L.; Tonn, C.E. Antiinflammatory Activity of Cinnamic Acid Esters. Molecules 2000, 5, 547-548. [CrossRef]

31. Deba, F.; Xuan, T.D.; Yasuda, M.; Tawata, S. Chemical composition and antioxidant, antibacterial and antifungal activities of the essential oils from Bidens pilosa Linn. var. Radiata. Food Control. 2008, 19, 346-352. [CrossRef]

32. Lambert, R.J.W.; Skandamis, P.N.; Coote, P.J.; Nychas, G.-J.E. A study of the minimum inhibitory concentration and mode of action of oregano essential oil, thymol and carvacrol. J. Appl. Microbiol. 2001, 91, 453-462. [CrossRef]

33. Tian, F.; Li, B.; Ji, B.; Yang, J.; Zhang, G.; Chen, Y.; Luo, Y. Antioxidant and antimicrobial activities of consecutive extracts from Galla chinensis:The polarity affects the bioactivities. Food Chem. 2009, 113, 173-179. [CrossRef]

34. Longbottom, C.J.; Carson, C.F.; Hammer, K.A.; Mee, B.J.; Riley, T.V. Tolerance of Pseudomonas aeruginosa to Melaleuca alternifolia (tea tree) oil is associated with the outer membrane and energy-dependent cellular processes. J. Antimicrob. Chemother. 2004, 54, 386-392. [CrossRef] [PubMed]

35. Dorman, H.J.D.; Deans, S.G. Antimicrobial agents from plants: Antibacterial activity of plant volatile oils. J. Appl. Microbiol. 2000, 88, 308-316. [CrossRef] [PubMed]

36. Burt, S. Essential oils: Their antibacterial properties and potential applications in foods-A review. Int. J. Food Microbiol. 2004, 94, 223-253. [CrossRef] [PubMed]

37. Kalpana, V.N.; Rajeswari, V.D. Preservatives in Beverages: Perception and Needs. In Preservatives and Preservation Approaches in Beverages [Internet]; Grumezescu, A.M., Holban, A.M., Eds.; Academic Press: Cambridge, MA, USA, 2019; pp. 1-30. Available online: http:/ / www.sciencedirect.com/science/article/pii/B978012816685700001X (accessed on 24 June 2020).

38. Cao, H.; Ke, T.; Liu, R.; Yu, J.; Dong, C.; Cheng, M.; Huang, J.; Liu, S. Identification of a Novel Proline-Rich Antimicrobial Peptide from Brassica napus. PLoS ONE 2015, 10, e0137414. [CrossRef] [PubMed]

39. Cai, R.; Miao, M.; Yue, T.; Zhang, Y.; Cui, L.; Wang, Z.; Yuan, Y. Antibacterial activity and mechanism of cinnamic acid and chlorogenic acid against Alicyclobacillus acidoterrestris vegetative cells in apple juice. Int. J. Food Sci. Technol. 2019, 54, 1697-1705. [CrossRef]

40. Kolla, N.K.J.; Peddikotla, P.; Muvva, V.; Venkateswarlu, Y.E.; Krishna, P.S. Biological activity of phenylpropionic acid isolated from a terrestrial Streptomycetes. Polish J. Microbiol. 2007, 56, 191-197.

41. Preethi, R.; Devanathan, V.V. Loganathan, M. Antimicrobial and Antioxidant Efficacy of Some Medicinal Plants Against Food Borne Pathogens. Adv. Biol. Res. 2010, 4, 122-125.

42. Hassan, R.; El-Kadi, S.; Sand, M. Effect of some organic acids on fungal growth and their toxins production. Int. J. Adv. Biology. 2015, 2, 1-11. [CrossRef] 
43. Fadli, M.; Saad, A.; Sayadi, S.; Chevalier, J.; Mezrioui, N.-E.; Pagès, J.-M.; Hassani, L. Antibacterial activity of Thymus maroccanus and Thymus broussonetii essential oils against nosocomial infection-Bacteria and their synergistic potential with antibiotics. Phytomedicine 2012, 19, 464-471. [CrossRef]

44. Okoh, O.O.; Sadimenko, A.P.; Afolayan, A.J. Comparative evaluation of the antibacterial activities of the essential oils of Rosmarinus officinalis L. obtained by hydrodistillation and solvent free microwave extraction methods. Food Chem. 2010, 120, 308-312. [CrossRef]

45. Tepe, B.; Donmez, E.; Unlu, M.; Candan, F.; Daferera, D.; Vardar-Unlu, G.; Polissiou, M.; Sokmen, A. Antimicrobial and antioxidative activities of the essential oils and methanol extracts of Salvia cryptantha (Montbret et Aucher ex Benth.) and Salvia multicaulis (Vahl). Food Chem. 2004, 84, 519-525. [CrossRef]

46. Dra, L.A.; Aghraz, A.; Boualy, B.; Oubaassine, S.; Barakate, M.; Markouk, M.; Larhsini, M. Chemical Characterization and In vitro Antimicrobial Activity of Caralluma europaea Essential Oil and Its Synergistic Potential with Conventional Antibiotics. J. Adv. Med Pharm. Sci. 2018, 19, 1-11. [CrossRef]

47. Helander, I.M.; Alakomi, H.L.; Latva-Kala, K.; Mattila-Sandholm, T.; Pol, I.; Smid, E.J.; Gorris, L.G.; von Wright, A. Characterization of the action of selected essential oil components on Gram-negative bacteria. J. Agric. Food Chem. 1998, 46, 3590-3595. [CrossRef]

48. National Research Council (US) Committee for the Update of the Guide for the Care and Use of Laboratory Animals. Guide for the Care and Use of Laboratory Animals [Internet], 8th ed.; The National Academies Collection: Reports funded by National Institutes of Health; National Academies Press: Washington, DC, USA, 2011. Available online: http:/ /www.ncbi.nlm.nih.gov/books/NBK5 4050/ (accessed on 9 May 2020).

49. Ho, C.-T.; Chen, Q.; Shi, H.; Zhang, K.-Q.; Rosen, R.T. Antioxidative effect of polyphenol extract prepared from various Chinese teas. Prev. Med. 1992, 21, 520-525. [CrossRef]

50. Kabran, G.R.M.; Mamyrbékova-Békro, J.A.; Pirat, J.-L.; Bekro, Y.-A.; Sommerer, N.; Verbaere, A.; Meudec, E. Identification de composés phénoliques extraits de deux plantes de la pharmacopée ivoirienne. J. Soc. Ouest Afr. Chim. 2014, $38,57-63$.

51. Ayoola, G.; Akpanika, G.; Awobajo, F.; Osunkalu, V.; Coker, H.; Odugbemi, T. Anti-Inflammatory Properties of the Fruits of Allanblanckia floribunda oliv. (Guttiferae). Bot. Res. Int. 2009, 2, 21-26.

52. Winter, C.A.; Risley, E.A.; Nuss, G.W. Carrageenin-Induced Edema in Hind Paw of the Rat as an Assay for Antiinflammatory Drugs. Proc. Soc. Exp. Biol. Med. 1962, 111, 544-547. [CrossRef]

53. Balouiri, M.; Sadiki, M.; Ibnsouda, S.K. Methods for in vitro evaluating antimicrobial activity: A review. J. Pharm. Anal. 2016, 6, 71-79. [CrossRef]

54. da Silveira, S.M.; Luciano, F.B.; Fronza, N.; Cunha, A.; Scheuermann, G.N.; Vieira, C.R.W. Chemical composition and antibacterial activity of Laurus nobilis essential oil towards foodborne pathogens and its application in fresh Tuscan sausage stored at $7{ }^{\circ} \mathrm{C}$. LWT Food Sci. Technol. 2014, 59, 86-93. [CrossRef]

55. Atki, Y.E.; Aouam, I.; El kamari, F.; Taroq, A.; Gourch, A.; Lyoussi, B.; Abdellaoui, A. Antibacterial efficacy of Thymol, Carvacrol, Eugenol and Menthol as alternative agents to control the growth of nosocomial infection-bacteria. J. Pharm. Sci. Res. 2019, 11, 4.

56. Furtado, G.; Medeiros, A. Single-disk diffusion testing (Kirby-Bauer) of susceptibility of Proteus mirabilis to Chloramphenicol: Significance of the intermediate category. J. Clin. Microbiol. 1980, 12, 550-553. [CrossRef] [PubMed] 